\title{
The Influence of Servant Leadership on Employee Trust in a Leader and Commitment to the Organization
}

\author{
Richard Chinomona \\ Department of Logistics, Vaal University of Technology \\ Private Bag X021, Vanderbij/park 1900, South Africa \\ E-mail: rchinos@hotmail.com \\ Moipone Mashiloane \\ David Pooe \\ Vaal University of Technology, South Africa
}

\section{Doi:10.5901/mjss.2013.v4n14p405}

\begin{abstract}
Servant leadership is a concept that has garnered attention from researchers in the past decade. Servant leadership requires leaders to rely on one-on-one communication in order to understand the abilities, needs, desires, goals, and potential of their followers and ultimately bring the best out of those individuals. It is noted from the extant literature that, with the knowledge of each follower's unique characteristics and interests, leaders can assist their followers in achieving their potential. This study investigates the mediating role of employee trust in the leader on the relationships between servant leadership and employee commitment to the organization. Three research hypotheses are posited and empirically tested using a sample data of 150 from certain sectors in South Africa's Gauteng Province. The results indicate that servant leadership positively influences employee trust in the leader and employee commitment to the organization in a significant way. Servant leadership implications of the findings are discussed and limitations and future research directions are indicated.
\end{abstract}

Keywords: Servant leadership, Employee trust, Employee commitment, Transformational leader, Social exchange theory

\section{Introduction}

Leadership is a complex relationship between the characteristics of the leader and the attitudes and needs of the followers to realize the purpose of the organization (Mc Gregor, 1960; Barbuto \& Wheeler, 2006). One of the leadership concept that has been popularized in the past decade is servant leadership (Barbuto \& Wheeler, 2002). Servant leadership is a philosophy and practice defined in the Bible by Jesus Christ, (in the Gospel of John Chapter 13). Among the known important effects of servant leadership in leadership and organizational behavior literature are employee trust and commitment (Gao, Janssen \& Shi, 2011). In the extant literature, employee trust is defined as an individual's reliance on another person under conditions of dependence and risk (Tschannen-Moran \& Hoy, 2000; Schoorman, Mayer \& Davis, 2007). Commitment is defined as a positive feelings of identification with, attachment to, and involvement in, the work organization" (Meyer \& Allen, 1997:375).

Although a substantive body of literature about the implications of servant leadership exists, less attention has been paid to mediating influence employee trust in the servant leadership and employee commitment relationship. It is therefore submitted in the current study that beside the direct effects of servant leadership on employee commitment, the employee's trust is an intervening construct in this relationship. In other words, if employees trust a leader who depicts servant leadership qualities, they are more likely to be committed to their organization. Moreover too, most of the previous researches conducted on servant leadership and the behavioral outcomes happen to be in the developed countries such as the USA and Europe and to some lesser extent the newly developed countries in the Asian world (Hunter, Neubert, Perry, Witt, Penny \& Weinberger 2012; Somers, 2008). Hence, there seem to be a dearth of studies that focus on the same, from an African perspective. In particular, researches that investigate the influence of servant leadership on employee trust and employee commitment to their organization in the African context remains scant, therefore the need for the current empirical study.

In light of the above, this research paper aims to achieve four objectives. First, this study seeks to examine the 
influence of servant leadership on employee trust in their leader. Second, it seeks to present an empirical investigation of the influence of servant leadership on employee commitment to their organization. Third, the paper seeks determine the influence of employee trust on employee commitment to their organization. Finally, an attempt is made to apply the Leader-Member Exchange theory (LMX theory) in the context of this study. This endeavor is considered to provide a strong theoretical grounding to the current research. All in all, the findings of this study are expected to contribute new knowledge to the existing body of servant leadership literature. In addition, it is expected to provide new or different aspects or perspectives of viewing implications of trust and commitment in the organization.

The rest of the article is organized as follows: a review of the literature, conceptual framework and hypotheses are provided. These are followed by the discussion of methodology, the constructs and construct measures used. The analysis as well as conclusion are outlined thereafter. Finally leadership implications, limitations and future research directions are provided.

\section{Literature Review}

\subsection{Leader-Member Exchange Theory}

According to Liden and Maslyn (1998), the Leader-Member Exchange (LMX) perspective is unique among leadership theories in that it focuses on dyadic relationships between leaders and followers. The theory contends that leaders form different types of exchange relationships with their respective followers (Dansereau, Graen \& Haga, 1975; Liden \& Maslyn, 1998). The LMX theory is silent with respect to the provision of personal healing, the development of followers and the encouragement of service to the community by leaders. Servant leadership is therefore related to LMX theory in that servant leadership behaviors contribute to the development and maintenance of strong interpersonal relationships between leaders and followers and are instrumental in helping employees attain their fullest potential and become selfmotivated (Manz \& Sims, 1987; Liden \& Maslyn, 1998). Leaders foster these important behaviors by forming social exchange relationships with their followers, rather than relying solely on the economic incentives in the employment agreement or the authority vested in their positions.

\subsection{Servant leadership}

The term 'servant' indicates an idea based on service or serving. The idea of servant leadership is deeply rooted in and originated from religion. Ancient scripture refers to the servant leader example of Jesus Christ. For example, Matthew recorded Jesus' words: "You know that the rulers of the Gentiles lord it over them, and their high officials exercise authority over them. Not so with you. Instead, whoever wants to become great among you must be your servant" (Matthew 20:25-26, New International Version). Servant leadership stresses personal integrity and serving others, including employees, customers, and communities (Liden, Wayne, Zhao \& Henderson 2008).

More recently, Ehrhart (2004) conducted a thorough review of the literature and identified seven dimensions of servant leadership. The first dimension involves forming relationships with followers, such as when servant leaders spend quality time and forge interpersonal bonds with their followers. Second, servant leaders empower followers (e.g., incorporating follower input on important managerial decisions). Servant leaders also help followers grow and succeed by providing opportunities to enhance follower skills. Fourth, servant leaders behave ethically. For instance, a servant leader will follow through on promises made to followers to demonstrate their adherence to strong ethical values. Fifth, these leaders demonstrate conceptual skills, such as balancing daily work with future vision. They also put followers first by promoting follower success. Finally, servant leaders create value for others outside the organization, such as encouraging followers to engage in community service opportunities outside of work. Liden, Wayne, Zhao \& Henderson (2008) suggest that servant leadership produces organizational success because it builds or creates a trusting, supportive community that fosters creativity and initiative. In this sense, servant leadership is the independent variable that causes or produces a culture or community of trust that in turn produces organizational success (Reinke 2004).

\subsection{Employee trust on the leader}

Although there is a growing body of research on trust, there are still differences of opinion on its definition. This study will examine trust by using the frequently cited definition that focuses on defining trust in terms of a 'willingness to be vulnerable' in one's relationship (Roger, Mayer, Davis \& Schoorman, 1995; Whitener, Brodt, Korsgaard \& Werner, 1998) 
with another person based on positive expectations regarding that person's behavior (Rousseau, Sitkin, Burt \& Camerer, 1998). In general, trust has been conceived as the extent to which people are willing to rely upon others and make themselves vulnerable to them (Frost, Stimpson \& Maughan, 1978; Tschannen-Moran \& Hoy, 2000). Based on this general definition, this study define an employee's trust in his or her leader as a psychological state involving positive expectations about the leader's intentions or behaviors with respect to oneself in situations entailing risk (Boon \& Holmes, 1991; Premeaux \& Bedeian, 2003). The empirical literature indicate that trust is strengthened or weakened due to the experiences, interactions, and context within which the relationship exists, trust is likely to develop differently in relation to team members, team leaders, and toward the organization as a whole (Burke, Sims, Lazzara \& Salas, 2007). Trustworthiness attributions have a strong, widespread influence upon people's reactions to leaders (Yang \& Mossholder, 2010). While acknowledging the importance of trust in leadership across levels and forms the current article will primarily focus on the trust that exists between a team member and his/her team leader. This study proposes that a leader who displays higher levels of positivity (represented by hope, efficacy, optimism, and resiliency), would be seen by others as being more competent and in turn trustworthy because these components have been demonstrated to be connected to higher levels of performance (Luthans, Avolio, Avey \& Norman, 2007). When a leader is transparent, "followers come to know what the leader values and stands for, and that the leader understands who they are as well. Furthermore, if such insights reveal high levels of congruence between the attributes, values, and aspirations of both parties, the level of trust will deepen" (Avolio, Gardner, Walumbwa, Luthans \& May, 2004).

\subsection{Employee commitment to the organization}

Employee organizational commitment is the employee's emotional attachment, identification with, and involvement in a particular organization (Naqvi \& Bashir, 2011). Commitment was initially defined and studied as a uni-dimensional construct tied either to one's emotional attachment to an organization (Porter, Steers, Mowday \& Boulian, 1974). As work in this area progressed, these views of commitment converged and a new, multidimensional framework was adopted based on three distinct but related forms of commitment: affective, continuance and normative (Allen \& Meyer, 1990). The affective dimension of commitment refers to an emotional attachment to and involvement with an organization while continuance commitment denotes the perceived costs of leaving an organization (Meyer \& Allen, 1991). Normative commitment is a newer addition to the commitment typology and is viewed as felt responsibility to support and remain a member of an organization (Allen \& Meyer, 1990). However, despite these development of conceptualizing organizational commitment as a multi-dimensional construct, the current study treats employee commitment to organization as a uni-dimensional variable. Among the known empirical behavioral outcomes of employee commitment to the organization are employees' willingness to embrace organizational change (Meyer, Srinivas, Lal \& Topolnytsky, 2007), and improved employee job performance (Taylor, Burklund, Eisenberger, Lehman, Hilmert \& Lieberman, 2008; Coelho, Augusto, Coelho \& Sà, 2010).

\section{Conceptual Model and Hypothesis Development}

Based on the literature reviewed the following conceptual model has been developed. Hypothesized relationships between research variables are developed thereafter. In the conceptualized model servant leadership is the predictor variable, employee trust on the leader serves as the mediator and employee commitment is the outcome variable.

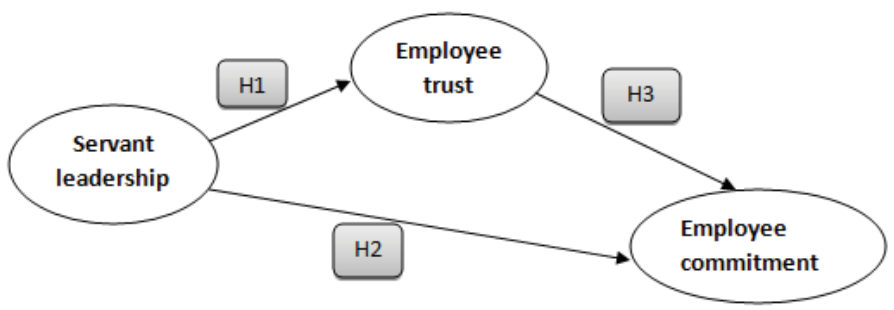

Figure 1: Conceptual Model 


\subsection{Servant Leadership and Employee Trust}

According to Bennis (2002) and DePree (2002), leaders generate and sustain through their behaviors. For instance, Gimbel, (2001) argues that trust seems to be determined primarily by the behavior of the leader's communicative and supportive behaviors. Leaders' communication practices that resemble humbleness and empathy with subordinates positively influences the followers' trust in the leader (Tschannen-Moran \& Hoy, 1998; Woolston, 2001). Thus, it is posited in the current study that the follower's trust in the leader is a product of servant leadership qualities. Based on the LMX theory and the above mentioned literature, this study therefore hypothesizes that:

H1:There is a positive relationship between servant leadership and employee trust in the leader.

\subsection{Servant Leadership and Employee Commitment to the Organization}

Theoretically and empirically, organizational commitment appears to be likely impacted by servant leaders. For example, Agrawal, A. A., S. Tuzun, \& E. Bent, Eds. (1999.) found one of the strong components of servant leadership characteristic attributes such as consideration behavior to be positively correlated with organizational commitment and involvement of employees in the organizational activities. Buttressing the same notion, Drucker (1999) argues that organizations are now evolving toward structures in which rank entails responsibility but not authority, and where the supervisor's job is not to command, but to persuade. This means that the influential role played by leaders through upholding values such as humbleness, empathy and empowerment is critically important in ensuring employee commitment to their organization. Thus, servant leaders assist and support their employees' growth, needs, and motivate them to carry out their duties to the fullest expectation of the organization (Blickle, 2003). In light of the aforementioned arguments, this study hypothesizes that:

H2: There is a positive relationship between servant leadership and employee commitment to the organization.

\subsection{Employee Trust and Employee Commitment}

They is growing empirical evidence indicating that employees' happiness is positively and significantly affected by trust and identification with one's co-workers - for example, their leaders (King \& Grace, 2008; Johnson et al., 2003). Moreover, greater levels of purpose that one attributes to his or her work correlates to a greater employee commitment to the organization. It also applies for the level of trust that the leader has cultivated among his or her subordinates. It is noted in the extant literature that productive employees are a result of a winning combination of trust and support (Gounans, 2005; Johnson et al., 2003). It is therefore important for leaders to build and manage employees' commitment, especially based on trust, because employees tend to show a huge amount of commitment towards the organization when the leader is trustworthy and reliable (King \& Grace, 2008). Drawing from the foregoing discussion, the current study therefore hypothesizes that:

H3: There is a positive relationship between trust in a leader and employee commitment to the organization.

\section{Research Methodology}

\subsection{Sample and data collection}

The data for this research was collected from different employees in Sharpeville in Gauteng Province of South Africa. Learners from the Tshepiso area in Sharpeville were recruited to distribute and collect the questionnaires after appointments with targeted employees. Of the total of 150 questionnaires distributed, 146 usable questionnaires were retrieved for the final data analysis.

\subsection{Measurement Instrument and Questionnaire Design}

Research measures were operationalized on the basis of previous work. Proper modifications were made in order to fit the current research context and purpose. "Servant leadership" measure used twenty items adapted from Erhart (2004), while "employee trust" used a six items all adapted from (Treadway, Hochwarter, Ferris, Kacmar, Douglas, Ammeter \& Buckely, 2004; Mayer et al, 1995), and "employee commitment" used eight items adapted from Meyer, Allen and Smith (1993). All the measurement items were measured on a five-point Likert-type scale that was anchored by $1=$ strongly 
disagree to $5=$ strongly agree to express the degree of agreement.

\subsection{Respondent Profile}

Table 1 presents the profile of the participants. The respondents were asked to indicate their demographic information, including gender, age, work position, sector and academic qualifications. The respondents were mainly females constituting $52.7 \%$ while males constituted $47.3 \%$. Data gathered indicated that $29.5 \%$ of respondents were people aged from 26-35 years, 26.7\% were aged between 36-45years, 22\% were aged between 20-25, 11.6\% were aged between 46-55 and $9.6 \%$ were $56 y$ years and above. The profile also indicates that $45.2 \%$ of respondents worked in other sectors not mentioned in the study and about $30.8 \%$ of respondents work as general workers. It is also quite clear from data collected that most of the respondents had post graduate degrees $45.2 \%$. Majority of respondents were from finance and construction which both constitute $11 \%$.

Table 1: Sample Profile Characteristics

\begin{tabular}{|c|c|c|}
\hline Gender & Frequency & Percentage \\
\hline Male & 69 & $47.3 \%$ \\
\hline Female & 77 & $52.7 \%$ \\
\hline Total & 146 & $100 \%$ \\
\hline & & \\
\hline Age & Frequency & Percentage \\
\hline $20-25$ & 33 & $22.6 \%$ \\
\hline $26-35$ & 43 & $29.5 \%$ \\
\hline $36-45$ & 39 & $26.7 \%$ \\
\hline $46-55$ & 17 & $11.6 \%$ \\
\hline $56+$ & 14 & 9.6 \\
\hline Total & 146 & $100 \%$ \\
\hline
\end{tabular}

\section{Data Analysis}

\subsection{Structural Equation Modeling Approach}

In order to statistically analyze the measurement and structural models, this study used Smart PLS software for Structural Equation Modeling (SEM) technique (Ringle et.al 2005). In SEM, the measurement model refers to the linkages between the latent variables and their manifest variables and the structural model captures the hypothesized causal relationships among the research constructs (Chin \& Newsted, 1999). Unlike AMOS and LISREL which are covariance-based approaches, Smart PLS is a regression based technique that originates from path analysis. Smart PLS has emerged as a powerful approach to study causal models involving multiple constructs with multiple indicators (Chinomona \& Surujal, 2012). Smart PLS, a component-based method, has the ability to model latent constructs that are uncontaminated by measurement error under conditions of non-normality. It has the ability to handle complex predictive models in small-to-medium sample sizes. Since the current study sample size is relatively small (150), Smart PLS was found to be more appropriate and befitting the purpose of the current study. In this respect, Bootstrapping resampling method was used to test the statistical significance of the relationships. The evidence on the reliability and validity of the measurement model is presented in Table 2.

\subsection{Measurement Model}

To ensure convergent validity, the researcher checked if items loaded on their respective (a priori) constructs with loadings greater than 0.5 , while discriminant validity was checked by ensuring that there was no significant inter-research variables cross-loadings (Chin, 1998). As can be seen in Table 2, all items have loadings greater than 0.5 (i.e. ranging from 0.509 to 0.875 ), with no cross-loadings greater than 0.728 , while t-statistics derived from bootstrapping (300 resamples) suggest all loadings are significant at pb0.001. As such, this confirms that all the measurement items converged well on their respective constructs and therefore are acceptable measures. 
Table 2: Accuracy Analysis Statistics

\begin{tabular}{|c|c|c|c|c|c|c|c|c|}
\hline \multicolumn{2}{|c|}{$\begin{array}{l}\text { Research } \\
\text { Construct }\end{array}$} & $\begin{array}{l}\text { LV Index } \\
\text { Value }\end{array}$ & $\begin{array}{l}\text { R-Squared } \\
\text { Value }\end{array}$ & $\begin{array}{c}\text { Cronbach's } \alpha \\
\text { value }\end{array}$ & $\begin{array}{l}\text { C.R. } \\
\text { Value }\end{array}$ & $\begin{array}{l}\text { AVE } \\
\text { Value }\end{array}$ & Communality & $\begin{array}{c}\text { Factor } \\
\text { Loading }\end{array}$ \\
\hline \multirow{20}{*}{ SL } & SL 1 & \multirow{20}{*}{3.798} & \multirow{20}{*}{0.000} & \multirow{20}{*}{0.944} & \multirow{20}{*}{0.950} & \multirow{20}{*}{0.500} & \multirow{20}{*}{0.500} & 0.509 \\
\hline & SL 2 & & & & & & & 0.628 \\
\hline & SL 3 & & & & & & & 0.616 \\
\hline & SL 4 & & & & & & & 0.594 \\
\hline & SL 5 & & & & & & & 0.687 \\
\hline & SL 6 & & & & & & & 0.658 \\
\hline & SL 7 & & & & & & & 0.562 \\
\hline & SL 8 & & & & & & & 0.748 \\
\hline & SL 9 & & & & & & & 0.712 \\
\hline & SL 10 & & & & & & & 0.759 \\
\hline & SL 11 & & & & & & & 0.686 \\
\hline & $\mathrm{SL} 12$ & & & & & & & 0.708 \\
\hline & SL 13 & & & & & & & 0.621 \\
\hline & SL 14 & & & & & & & 0.781 \\
\hline & SL 15 & & & & & & & 0.732 \\
\hline & SL 16 & & & & & & & 0.788 \\
\hline & SL 17 & & & & & & & 0.736 \\
\hline & $\mathrm{SL} 18$ & & & & & & & 0.782 \\
\hline & $\mathrm{SL} 19$ & & & & & & & 0.815 \\
\hline & SL 20 & & & & & & & 0.798 \\
\hline \multirow{6}{*}{ ET } & ET 1 & \multirow{6}{*}{4.041} & \multirow{6}{*}{0.649} & \multirow{6}{*}{0.921} & \multirow{6}{*}{0.921} & \multirow{6}{*}{0.719} & \multirow{6}{*}{0.719} & 0.774 \\
\hline & ET 2 & & & & & & & 0.860 \\
\hline & ET 3 & & & & & & & 0.860 \\
\hline & ET 4 & & & & & & & 0.875 \\
\hline & ET 5 & & & & & & & 0.854 \\
\hline & ET 6 & & & & & & & 0.861 \\
\hline \multirow{8}{*}{ EC } & EC 1 & \multirow{8}{*}{4.156} & \multirow{8}{*}{0.525} & \multirow{8}{*}{0.880} & \multirow{8}{*}{0.892} & \multirow{8}{*}{0.552} & \multirow{8}{*}{0.552} & 0.811 \\
\hline & $\mathrm{EC} 2$ & & & & & & & 0.767 \\
\hline & EC 3 & & & & & & & 0.763 \\
\hline & $\mathrm{EC} 4$ & & & & & & & 0.784 \\
\hline & EC 5 & & & & & & & 0.542 \\
\hline & EC 6 & & & & & & & 0.601 \\
\hline & EC 7 & & & & & & & 0.826 \\
\hline & EC 8 & & & & & & & 0.798 \\
\hline
\end{tabular}

Note: SL = Servant Leadership; ET = Employee Trust; EC = Employee Commitment , C.R.: Composite Reliability; AVE: Average Variance Reliability, ${ }^{*}$ Scores: 1 - Strongly Disagree; 3 - Moderately agree; 5 - Strongly Agree

According to Chin (1998), research variables should have an average variance extracted (AVE) of more than 0.5 and a composite reliability of more than 0.7 (convergent validity), and inter-construct correlations should be less than the square-root of the AVE (discriminant validity). As can be seen (Table 2), all constructs exceed these criteria, with AVE and CR generally equal or greater than 0.5 and 0.8 , respectively. Furthermore, as indicated in Table 3 , the square-root of the lowest AVE is 0.71 and is greater than the highest inter-construct correlation value (0.701). All in all, these results confirm the existence of discriminant validity of the measurement used in this study.

Table 3: Correlations between Constructs

\begin{tabular}{|l|l|l|l|}
\hline \hline Research Constructs & SL & ET & EC \\
\hline Servant Leadership (SL) & 1.000 & & \\
\hline Employee Trust (ET) & 0.805 & 1.000 & \\
\hline Employee Commitment (EC) & 0.701 & 0.672 & 1.000 \\
\hline \hline
\end{tabular}




\subsection{Path Model}

PLS also generates the path coefficients for the relationships modeled among the constructs. The significance of these coefficients was assessed using the bootstrap procedure (with 300 sub-samples) that provided the t-values for each path estimate. Figure 2 and Table 4 presents the results of the PLS analysis on the structural model along with the path estimates and t-values. Support for the study hypotheses, which are labeled on their corresponding paths in Figure 2, could be ascertained by examining the directionality (positive or negative) of the path coefficients and the significance of the t-values. The standardized path coefficients are expected to be at least 0.2 and preferably greater than 0.3 (Chin, et.al 1998).

Figure 2: Measurement and Structural Model Results

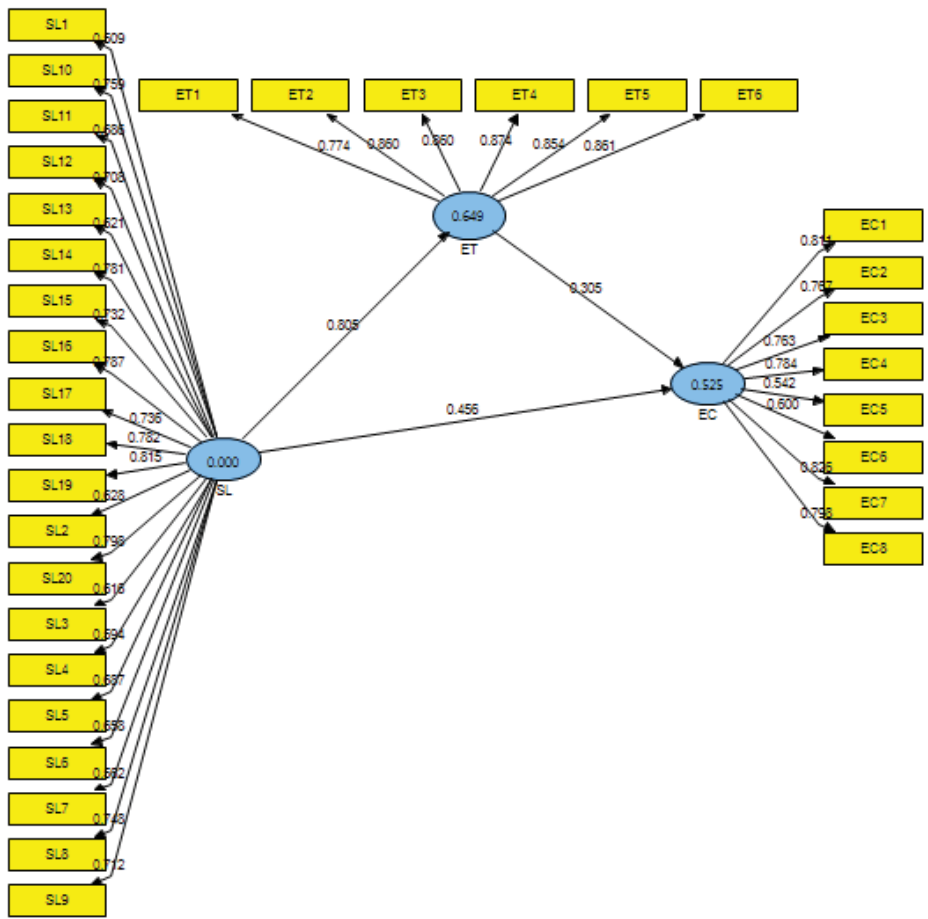

Note: SL = Servant Leadership; $\mathrm{ET}=$ Employee Trust; $\mathrm{EC}=$ Employee Commitment

The results revealed in Figure 2, presents the impact of servant leadership (SL) on employee trust on the leader (ET) and employee commitment to their organization (EC). As posited in the current study, Figure 2, indicates that SL has a positive influence on $E T$ ( $\beta=0.805, t=22.591)$, hence supporting $H 1$. Regarding the impact of $S L$ on $E C$, the results show that $S L$ has a positive relation with $E C(\beta=0.456, t=3.781)$, thus $H 2$ was supported. The results also demonstrate that $E C$, is also positively influenced by $E T(\beta=0.305, t=2.93)$, hence, supporting $H 3$. Premised on the current research findings, support for all the three hypotheses is provided, hence, resulting in a positive triangular relationship between SL, ET and EC. The, extant literature has also highlighted the important fostering role played by servant leadership on employee trust in the leader and the resultant employee commitment.

Table 4: Results of Structural Equation Model Analysis

\section{Proposed Hypothesis Relationship}

\begin{tabular}{|l|l|l|l|l|} 
Hypothesis & Path Coefficients & T-Statistics & Rejected/ Supported \\
\hline
\end{tabular}

\begin{tabular}{c|c|c|c|c}
\hline Servant Leadership (SL) $\rightarrow$ Employee Trust (ET) & H1 & 0.805 & 22.591 & Supported \\
Servant Leadership (SL) $\rightarrow$ Employee Commitment (EC) & H2 & 0.456 & 3.781 & Supported \\
Employee Trust (ET) $\rightarrow$ Employee Commitment (EC) & H3 & 0.305 & 2.93 & Supported
\end{tabular}

\section{Supported}

Note: SL = Servant Leadership; ET =Employee Trust; EC = Employee Commitment 
The $\mathrm{R}^{2}$ values for the two dependent variables - ET and EC- are 0.649 , and 0.525 respectively. These results reveal that, ET explains the $64.9 \%$ of the variance in employee trust, hence suggesting that servant leadership could be associated with employee trust in the leader. However, the results for employee commitment indicate that servant leadership and employee trust in the leader together, explain the $55.2 \%$ of variance in employee commitment to the organization.

Following formulae provided by Tenenhaus, Vinzi, Chatelin and Lauro (2005), the calculated global goodness-of-fit (GoF) statistic for the research model was 0.374 , which exceed the threshold of GoF>0.36 suggested by Wetzels, Odekerken-Schröder and van Oppen (2009). Thus, this study concludes that the research model has a good overall fit.

\section{Discussion and Conclusion}

The purpose of this study was to investigate the influence of servant leadership on employee trust on the leader and employee commitment to the organization. In particular, three hypotheses were postulated. To test the proposed hypotheses, data were collected from different industries in the Gauteng province of South Africa. The empirical results supported all the three posited research hypotheses in a significant way.

When the influence of servant leadership on employee trust was tested, a positive and significant influence was found. Thus, accordingly, as team leaders continue to serve their team members and followers, without assuming any authority or rank, but performing their responsibilities, trust for that particular team leader is stimulated within the followers. The findings of this paper confirm the work of other empirical studies such as Gimbel (2001) and Reinke (2004). Therefore, this paper concludes that servant leadership has a strong positive and significant influence on employees' trust of their leader.

Also, when the effect of servant leadership on employee's commitment to the organization was tested, the findings indicated a positive and significant influence. It is understood that the behavior of a leader that manifests through serving employees or followers, as well as upholding the values such as empowerment, humility and empathy will make the employees to involve themselves and be attached to their organization. As such, this paper submits that servant leadership has a strong positive influence on employee's commitment to an organization.

The influence of employee trust of their leader on employee's commitment to the organisation was also tested, and the findings revealed a positive and significant relationship. This finding confirm the previous works of Gounans (2005) as well as King and Grace (2008) who qualified that employee trust of their leader has a positive effect on employee commitment to the organisation. Therefore, where employees have trust for their leader, they become more committed to the organisation, as they perceive leaving the organisation as a costly decision to make. Accordingly, this study concludes that employee's trust in servant leadership qualities has a positive and significant influence on the employee's commitment to the organization. Also, based on these findings, this study deduces that that servant leadership has strong influence on employee commitment via employee trust. Perhaps this could be due to the fact that employees are more committed when supported by appropriate styles of leadership.

\subsection{Implications of the study}

The cumulative importance of servant leadership on organizations' performance in South Africa cannot be overemphasized. In particular, the efficacy of these organizations might be difficult to achieve without the correct leadership style. The current study was an attempt to undertake a research in an often most neglected research setting but yet investigating an important aspect of leadership styles - servant leadership. Therefore, the findings of this empirical study are expected to provide fruitful implications to both practitioners and academicians.

On the practitioners' side, important influential role of servant leadership and employee trust on employee commitment to the organization is highlighted. This study therefore submits that leaders and managers of different organizations should consider adopting servant leadership style in leading teams in order to obtain employees' commitment to their organizations. The understanding is that, managers set a tone that influences the way employees feel about their employer and consequently, the way they perform for and interact with customers (Allen \& Grisaffe, 2001). Servant leadership stresses personal integrity and serving others, including employees, customers and communities. With no confidence shaken in business leadership, interest has been increasing in the development of leaders who set aside self-interest for the betterment of their followers and organizations (Boyatzis \& McKee, 2005; George, 2003).

On the academic side, this study makes a significant contribution to the leadership literature by systematically 
exploring the impact of servant leadership on employee trust and employee commitment in line with different organizations. In particular, the current study findings provide tentative support to the proposition that servant leadership should be recognized as significant antecedent and tool to foster employee trust in the leader and employee commitment to the organization in different sectors.

\subsection{Limitations and Future Research}

Although this study makes significant contributions to both academia and practice, it was limited in some ways, and therefore some future research directions are suggested. First, the data were gathered from certain sectors in Gauteng Province of South Africa. Perhaps, the results would be more informative if data from all sectors in other provinces of the country are included. Future studies may be conducted by using data from other industry's or sectors across the country. Second, the current study was limited to sectors in South Africa. Consequent research should contemplate replicating this study in other developing countries in Africa for results comparisons. Future studies can also extend the current study conceptual framework by studying the effects of a larger set of variables. Above and beyond, this will immeasurably contribute new knowledge to the existing body of servant leadership literature on different organizations in developing countries which happen to be overlooked in research contexts in academics.

\section{References}

Agrawal, A. A., Tuzun, S., \& Bent, E. 1999. Induced plant defenses against pathogens and herbivores: biochemistry, ecology, and agriculture. American Psychopathological Society Press, St. Paul, MN.

Allen N.J \& Meyer J.P. 1997. The Measurement and Antecedents of Affective, Continuance and Normative Commitment to the Organization. Journal of Occupational Psychology, 63, 1-18.

Avolio, B.J. Gardner, W. L. Walumbwa, F.O. Luthans, F. \& May, D.R. 2004. Unlocking the mask: A look at the process by which authentic leaders impact follower attitudes and behaviors. The Leadership Quarterly, 15, 801-823.

Barbuto, J. E \& Wheeler, D. W. 2002. Becoming a servant leader: Do you have what it takes? Neb-Guide G02-1481-A. Lincoln: University of Nebraska, Nebraska Cooperative Extension.

Barbuto, J. E \& Wheeler, D. W. 2006. Scale Development and construct clarification of servant leadership. Group \& Organizational Management, 31(3), 300-236.

Bennis, W. 2002. Become a tomorrow leader, in Spears, L.C. (Eds), Focus on Leadership: Servant-Leadership for the 21st Century, Wiley, New York, NY, pp.101-9.

Boon, S. \& Holmes, J. 1991. The dynamics of interpersonal trust: Resolving uncertainty in the face of risk. In Hindle, R. \& Groebel, J. (Eds.). Cooperation and Prosocial Behavior, (167- 182). New York: Cambridge University Press.

Boyatzis, R. \& Mckee, A. 2005. Resonant Leadership: Renewing Yourself and Connecting With Others Through Mindfulness, Hope, and Compassion. Boston: Harvard Business School Press.

Burke, C.S. Sims, D.E. Lazzara, E.H. Salas, E. 2007. Trust in leadership: A multi-level review and integration. The Leadership Quarterly, $18,606-632$.

Chin W \& Newsted P.R. 1999. Structural Equation Modeling Analysis with small samples using partial least squares. In: Statistical Strategies for Small Sample Research, Hoyle R. Editors. Thousand Oaks, CA: Sage, 307-41.

Chin, W.W. 1998. Issues and opinion on structural equation modeling. MIS Quarterly, 22(1), 7- 16.

Chinomona, R \& Surujal, B. 2012. The influence of student internship work experience on their self-improvement and professionalism in Sport Management. African Journal for Physical, Health Education, Recreation and Dance, 18(4): 885-899.

Dansereau, F. Graen, G.B. \& Haga, W. 1975. A vertical dyad linkage approach to leadership in formal organizations. Organizational Behavior and Human Performance, 13, 46-78. Drucker P.F. 1999. Management Challenges for the 21st Century, ButterworthHeinemann, Oxford.

Ehrhart, M. G. 2004. Leadership and procedural justice climate as antecedents of unit-level organizational citizenship behavior. Personnel Psychology, 57, 61 - 94.

Ellis, K., Shockley-Zalabak, P. 2001. Trust in top management and immediate supervisor: the relationship to satisfaction, perceived organizational effectiveness, and information receiving. Communication Quarterly, 49(4), 382-99.

Frost, T. Stimpson, D.V. Maughan, M.R.C. 1978. Some Correlates of Trust. Journal of Psychology, 99, 103-108.

Gao, L. Janssen, O. \& Shi, K. 2011. Leader trust and employee voice: The moderating role of empowering leader behaviors. Leadership Quarterly, 22, 787-798.

Gimbel, P.A. 2001. Understanding principal trust-building behaviors: evidence from three middle schools. Dissertation Abstracts International, UMI No. 3018320.

Hunter, E. Neubert, M.J. Perry, S.J. Witt, L A. Penney, L.M. Weinberger, E. 2012. Servant Leaders Inspire Servant Followers: Antecedents and outcomes for Employees and the Organization. Leadership Quarterly, 21, 677-691.

King, C. \& Grace, D. 2008. Internal branding: Exploring the employees' perspective. The Leadership Quarterly, 20, 116-130.

Liden, R. C. \& Maslyn, J.M. 1998. Multidimensionality of leader-member exchange: An empirical assessment through scale 
development. Journal of Management, 24, 43-72.

Linden, R. C. Wayne, S. J. Zhao, H. \& Henderson, D. 2008. Servant leadership: Development of a multidimensional measure and multilevel assessment. The Leadership Quarterly, 19, 161-177.

Luthans, F. Avolio, B.J. Avey, J.B. \& Norman, S.M. 2007. Positive Psychological Capital: Measurement and Relationship with Performance and Satisfaction. Published in Personnel Psychology 60, 541-572.

Manz, C.C. \& Sims, H.P. Jr. 1987. Leading workers to lead themselves: The external leadership of self-managing work teams. Administrative Science Quarterly, 32, 106-128.

Mark, J.S. 2001. Ethical Codes of Conduct and Organizational Context: A Study of the Relationship between Codes of Conduct, Employee Behavior and Organizational Values. Journal of Business Ethics 30 (2), 185 - 195.

Mcgregor, D. 1960. The Human Side of Enterprise, New York, McGraw Hill.

Meyer J.P \& Allen N.J. 1997. Commitment in the Workplace: Theory, Research, and Application. Thousand Oaks, CA: Sage Publications.

Meyer, J.P \& Allen, N.J. 1991. A three-component conceptualization of organizational commitment: Some methodological considerations. Human Resource Management Review, 1, 61-98.

Meyer, J.P. Srinivas, E.S. Lal, J.B. \& Topolnytsky, L. 2007. Employee commitment and support for an organizational change: Test of the three-component model in two cultures. Journal of Occupational and Organizational Psychology, 80(2), 185-211.

Naqvi, S.M.M. R. \& Bashir, S. 2011. IT-Expert Retention through Organizational Commitment: A study of Public Sector Information Technology Professionals in Pakistan, Journal of Saudi Computer Society, Applied Computing and Informatics, 9

Porter, L.W. Steers, R.M. Mowday, R.T. \& Boulian, P.V. 1974. Organizational commitment, job satisfaction, and turnover intention among psychiatric technicians. Journal of Applied Psychology, 59, 603-609.

Ringle, C. M. Wende, S \& Will, A. 2005. Smart PLS 2.0 M3. Available at http://www.smartpls.de.

Roger, C. Mayer, J. Davis, H. \& Schoorman, F.D. 1995. An Integrative Model of Organizational Trust. The Academy of Management Review, 20 (3): 709-734.

Rousseau, D.M. Sitkin, S.B. Burt, R.S. \& Camerer, C. 1998. Not so different after all: A cross-discipline view of trust. Academy of Management Review, 23, 393-404.

Taylor, S.E. Burklund, L.J. Eisenberger, N.I. Lehman, B.J. Hilmert, C.J. \& Lieberman, M.D. 2008. Neural bases of moderation of cortisol stress responses by psychosocial resources. Journal of Personality and Social Psychology 95(1), 197-211.

Tenenhaus, M. Vinzi, V. E. Chatelin, Y.M \& Lauro, C. 2005. PLS Path Modeling. Computational Statistics and Data Analysis, 48(1), 159-205.

Tschannen-Moran, M. \& Hoy, W. K. 2000. A multidisciplinary analysis of the nature, meaning, and measurement of trust. Review of Educational Research, 71, 547-593.

Wetzels, M. Odekerken-Schröder, G \& Van Oppen, C. 2009. Using PLS path modeling for assessing hierarchical construct models: Guidelines and empirical illustration.

Yang, J. \& Mossholder, K.W. 2010. Examining the effects of trust in leaders: A bases-and-foci approach. Leadership Quarterly, 21, 5063. 